\title{
MINERAL RESOURCE POTENTIAL OF THE FARLES PRAIRIE AND BUCK LAKE ROADLESS AREAS, MARION COUNTY, FLORIDA
}

By

\author{
James B. Catheart and Sam H. Patterson, U.S. Geological Survey \\ and
}

Thomas M. Crandall, U.S. Bureau of Mines

1983

Studies Related To Wilderness

Under the provisions of the Wilderness Act (Public Law 88-577, September 3, 1964) and related acts, the U.S. Geological Survey and the U.S. Bureau of Mines have been conducting mineral surveys of wilderness and primitive areas. Areas officially designated as "wilderness," "wild", or "canoe" when the act was passed were incorporated into the National Wilderness Preservation System, and some of them are presently being studied. The act provided that areas under consideration for wilderness designation should be studied for suitability for incorporation into the Wilderness System. The mineral surveys constitute one aspect of the suitability studies. The act directs that the results of such surveys are to be made available to the public and be submitted to the President and the Congress. This report discusses the results of a mineral survey of the Farles Prairie (08305) and Buck Lake (08306) Roadless Areas, Ocala National Forest, Marion County, Fla. The areas were classified as further planning areas during the Second Roadless Area Review and Evaluation (RARE II) by the U.S. Forest Service, January 1979.

\section{MINERAL RESOURCE POTENTIAL SUMMARY STATEMENT}

The Farles Prairie-Buck Lake Roadless Areas in the Ocala National Forest, Marion County, Fla., are underlain by phosphate-bearing sedimentary rocks. The deposits are low in $\mathrm{P}_{2} \mathrm{O}_{5}$ content and tonnage and are slightly high in the deleterious elements-magnesium, calcium, iron, and aluminum. In addition, the ratio of thickness-of-overbuden to thickness-of-phosphate rock is slightly high. The area has a low potential for oil and gas, indicated by numerous dry holes drilled in the vicinity and by the absence of the formations that produce hydrocarbons in south Florida and in western panhandle Florida. Nearly pure limestone deposits underlie the area, but they are too deeply buried. Sand has been mined from a pit in the Buck Lake Roadless Area, but virtually unlimited deposits of same are present in areas closer to markets. No peat is present in the area-the Holocene and Pleistocene sands that blanket the area are very low in total organic matter.

Kaolinitic and smectitic clays are present in the area, but have little value. The kaolinitic clays in the Citronelle(?) Formation contain too little clay (average only about 15 percent by weight of kaolinite in the total rock) to be of value. The lenticular beds of smectitic clay found in the Hawthorn Formation are too deeply buried to be minable.

Although heavy minerals are mined near Starke, about $60 \mathrm{mi}$ to the north of the areas, the heavy minerals in the surficial sand (ilmenite, garnet, rutile, zircon, staurolite, sillimanite, tourmaline, and kyanite) average about 0.4 percent, by weight, or about one-tenth as much as in the minable deposits.

The only mining in the area was of surficial clayey sand that was used as road metal, but virtually unlimited quantities of clayey sand are present at the surface outside of the Farles Pairie-Buck Lake study areas.

\section{INTRODUCTION}

The Farles Prairie and Buck Lake Roadless Areas are in the southeast part of the Ocala National Forest in Marion County, Fla., about $30 \mathrm{mi}$ east of the town of Ocala, Fla. (figs. 1 and 2). Farles Prairie Roadless Area is an irregular area of about 2,175 acres in parts of secs. 1, 2, 11, and 12, T. 16 S., R. 26 E. Buck Lake Roadless Area contains about 5,680 acres in parts or all of secs. $13,14,22,23,24,25,26$, and 27 , T. $16 \mathrm{~S}$., R. 26 E.

The area can be reached from ocala by taking State Road 40 about $32 \mathrm{mi}$ east to the junction of State Road 19, then south on this road about $2 \mathrm{mi}$ to Forest Service Road 62, which leads to the U.S. Navy
Tracking Station, about $1 \mathrm{mi}$ northeast of the corner of the Farles Prairie Roadless Area. Alternatively continue south on State Road 19 about $8 \mathrm{mi}$ to the junction of Forest Service Road 73, then west on this road about $4 \mathrm{mi}$ to Forest Service Road 66. The southwest corner of the Buck Lake Roadless Area is 1 mi north of this junction.

The Farles Prairie and Buck Lake Roadless Areas are in the Central Highlands physiographic province of Florida. The topography is a modified karst with a thin veneer of windblown sand at the surface. Farles Prairie Roadless Area consists of low sand hills in the eastern part and shallow lakes and flat prairies on the west. Elevations range from 50 to about $85 \mathrm{ft}$ above sea level (accompanying map, fig. 


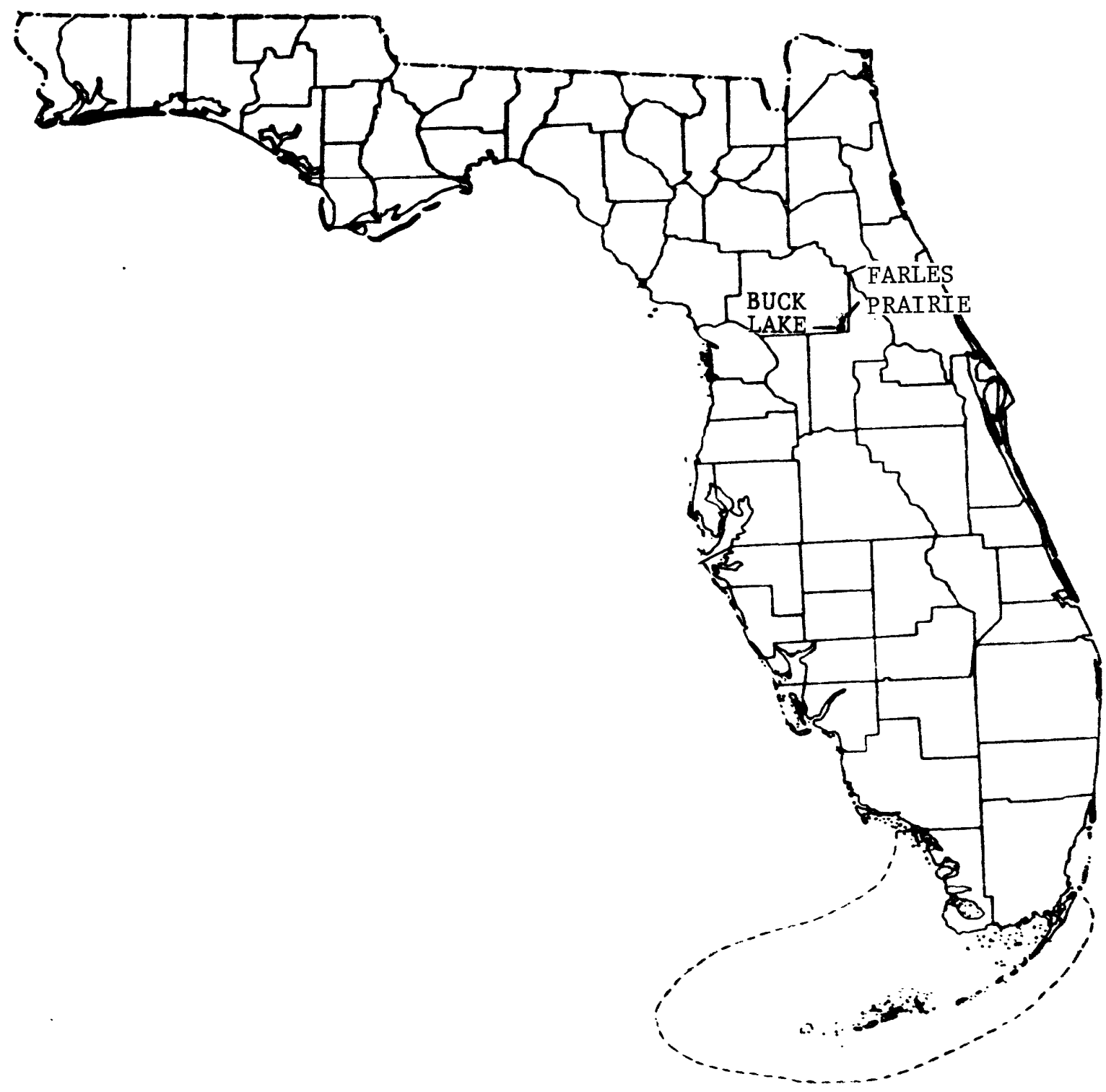

Figure 1.--Index map showing the location of Farles Prairie and Buck Lake Roadless Areas. 


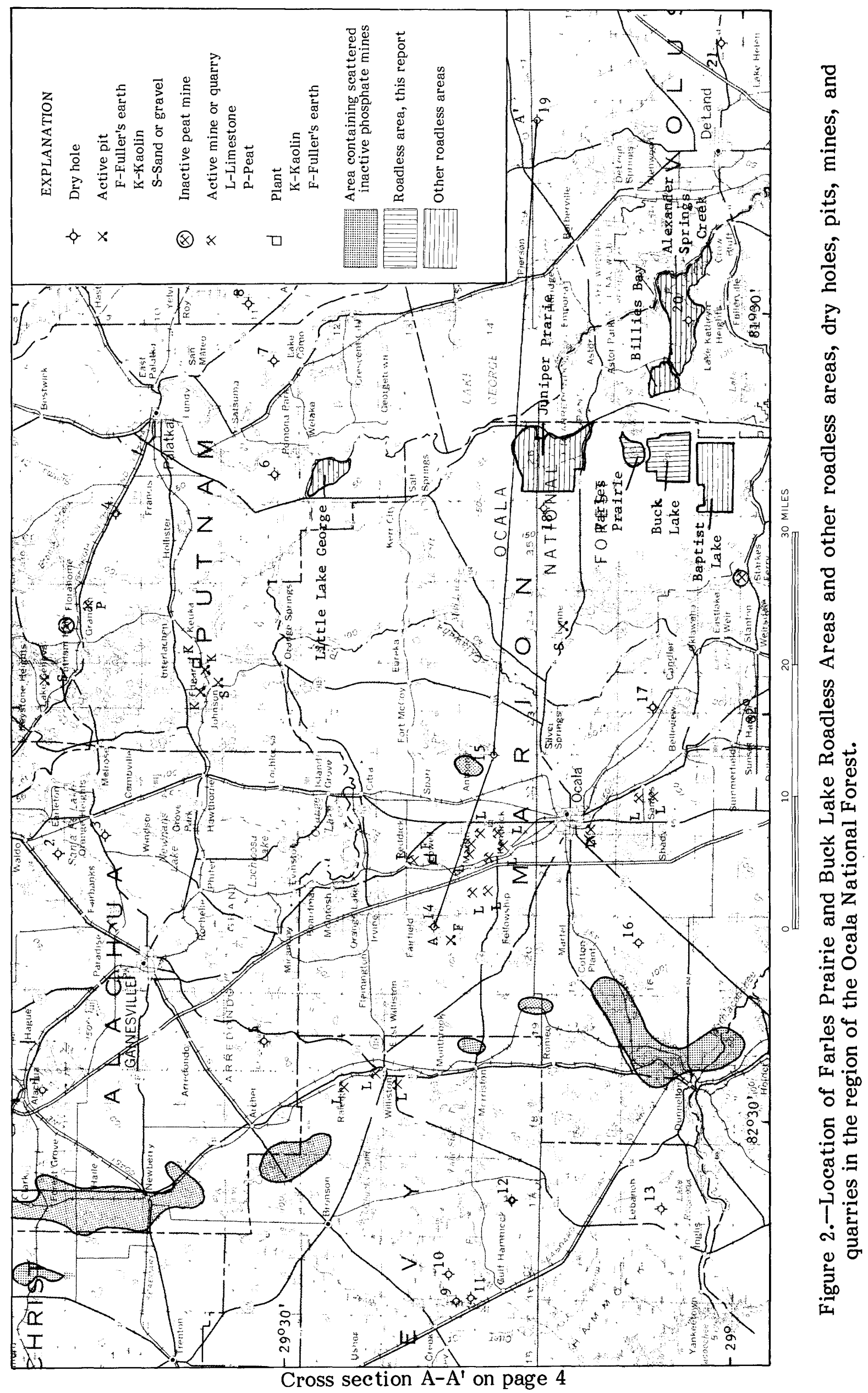




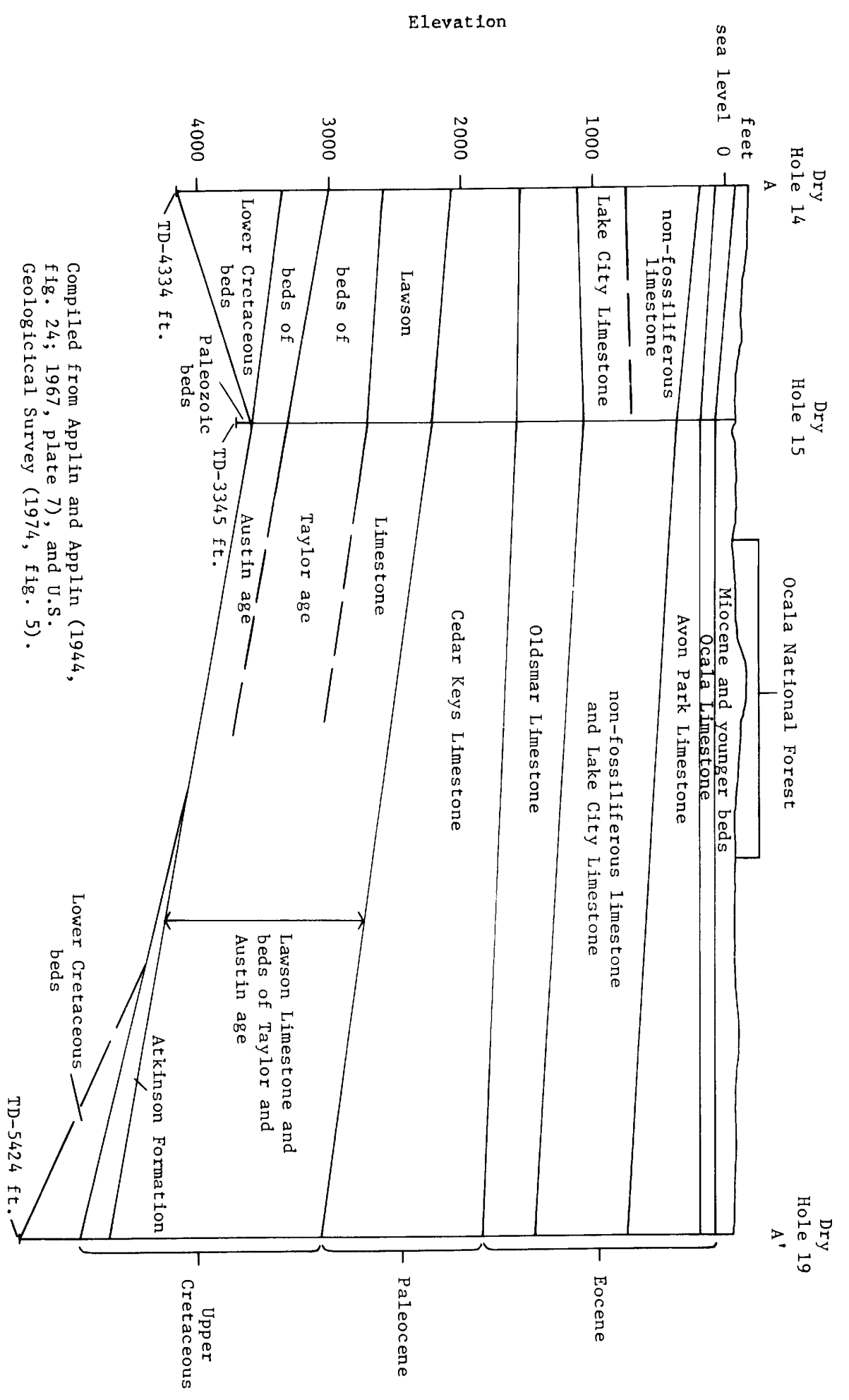

Cross section from figure 2 on page 3 
3). Buck Lake Roadless Area consists almost entirely of low sand hills; elevations range from $75 \mathrm{ft}$ at the northeast corner to about $140 \mathrm{ft}$ at the southwest corner. The sand hills are covered by pine forests with palmetto underbrush; the lower areas have the black gum-hickory type of vegetation. The surface soils in the sand hills are very low in organic content, containing only a few roots and minor organic remains. The wet prairies contain some swamp muck in the lower parts.

\section{Present Investigation}

Catheart and Patterson reviewed published information on the geology of the Ocala National Forest and reconnoitered the area in February 1980. Crandall reviewed published information on the mineral resources of the region and made a reconnaissance of the area in March 1980.

A drilling program was carried out jointly by the U.S. Geological Survey (USGS) and the U.S. Bureau of Mines (USBM) in September and October 1980. Two holes (fig. 3 , holes 3 and $3 \mathrm{~A}$ ) were drilled along the western boundary and one (fig. 3 , hole 4 ) at the northeast corner of the Buck Lake Roadless Area. In addition, two holes (fig. 3, holes 1 and 2) were drilled to the east and southeast of the study areas, one (fig. 3 , hole 5) some six miles north of Farles Prairie, and one (fig. 3 , hole 6 ) at the northern edge of the Ocala National Forest. A fishtail bit was used through the overburden; drilling was stopped and mud was circulated at $10 \mathrm{ft}$ intervals so that reasonable samples of the cuttings from the interval could be collected. With the first appearance of phosphate or dark olivegreen clay typical of the Hawthorn Formation, a core barrel was installed and the hole was cored to the very hard dolomite of the Hawthorn Formation. At this point a tricone bit was installed and the hole was drilled to the top of the Ocala Limestone. Core and cuttings were logged at the site and samples were collected for later investigation in the laboratory.

Seven large samples of the better phosphate rock were collected and were treated by Pembroke Laboratories, Bartow, Fla. Metallurgical and analytical data are shown on tables 3,4 , and 5 .

Information on oil and gas exploration holes in this report is based on published reports and on records on file in the Florida Bureau of Geology, Tallahassee, Fla.

No geochemical surveys were made during the field work because they would have provided no information of value in assessing the mineral potential of the area; heavy minerals in the rocks exposed at the surface are in concentrations far too low to form potentially valuable deposits.

\section{Previous Investigations}

The general geology of central Florida is discussed by Cooke (1945), Espenshade and Spencer (1963), and Puri and Vernon (1964). The geologic maps and descriptions by these writers have been used in the discussion of the geology in this report.

Subsurface geology of northern peninsular Florida is discussed in reports by Applin (1951), Applin and Applin (1944, 1965, and 1967), and Rainwater (1971).

Although there are no detailed surveys of the mineral resources of the Ocala National Forest, general information is included in the following references: Limestone (Schmidt and others, 1979); phosphate (Catheart, 1968; Espenshade and 'Spencer, 1963, Mansfield, 1942, Sever, Cathcart, and Patterson, 1967); clay (Calver, 1949); peat (Davis, 1946); and heavy minerals (Garner, 1972, 1981).

\section{Acknowledgments}

The authors are grateful for the cooperation of the Florida Bureau of Geology and the U.S. Forest Service. Thomas M. Scott, geologist with the Florida Bureau worked with Catheart and Crandall during the drilling program and helped in logging and sampling core and cuttings. Richard J. Deuerling, Jr. of the Florida Bureau logged two of the drill holes with the gamma-ray logging unit and assisted in sampling. Discussions with these geologists were of great value in making stratigraphic interpretations from lithology. David Curry and F.A. Pontigo, Jr. of the Florida Bureau aided in gathering information on oil and gas. George Hemingway, District Ranger, Seminole Area, and Bobby Brady, District Ranger, Lake George Area of the Ocala National Forest, provided maps and storage facilities for drilling equipment. William R. Waite, soil scientist, U.S. Forest Service, Tallahassee, Fla., provided maps and background information on the region.

\section{SURFACE- AND MINERAL-RIGHTS OWNERSHIP}

The Federal Government owns all surface and mineral rights in the study area. Public domain and acquired lands are shown in figure 4.

Public domain lands in Florida are subject to mineral location under the authority of the 1872 Mining Law. However, lode and placer deposits are not believed to be present in the study areas and location of valid mining claims do not appear possible. Phosphate is leasable under the authority of the Mineral Leasing Act of 1920 for public domain lands and the Mineral Leasing Act of 1947 for acquired lands. As of January 1981, there were no leases or applications for leases in or near the study areas.

\section{GEOLOGY}

The Farles Prairie and Buck Lake Roadless Areas are covered by a thin veneer of unconsolidated surficial sediment of probable Holocene age. The sediment consists of white sand or slightly clayey sand with only minor amounts of organic matter and roots. In most places the surficial sediments are no more than $5 \mathrm{ft}$ thick, but a few company drill holes penetrated as much as $100 \mathrm{ft}$ of unconsolidated sediment described as sand and humus, slightly clayey sand with organic matter, and so on. The greatest thicknesses of unconsolidated sediments are sink-hole fillings. Organic muck and humus accumulations are present in many of the swampy areas, but neither study area contain significant deposits of peat.

The surficial sand is underlain by a second layer of clayey sand that is of uncertain age because it contains no fossils. However, this sand is lithologically identical with the Pliocene Citronelle Formation which is shown as cropping out in the area on the geologic map of Espenshade and Spencer (1963) and is probably of Pliocene and Pleistocene age. The Citronelle Formation will be tentatively used in this report. This formation is, in a sense, the bedrock unit in the two 


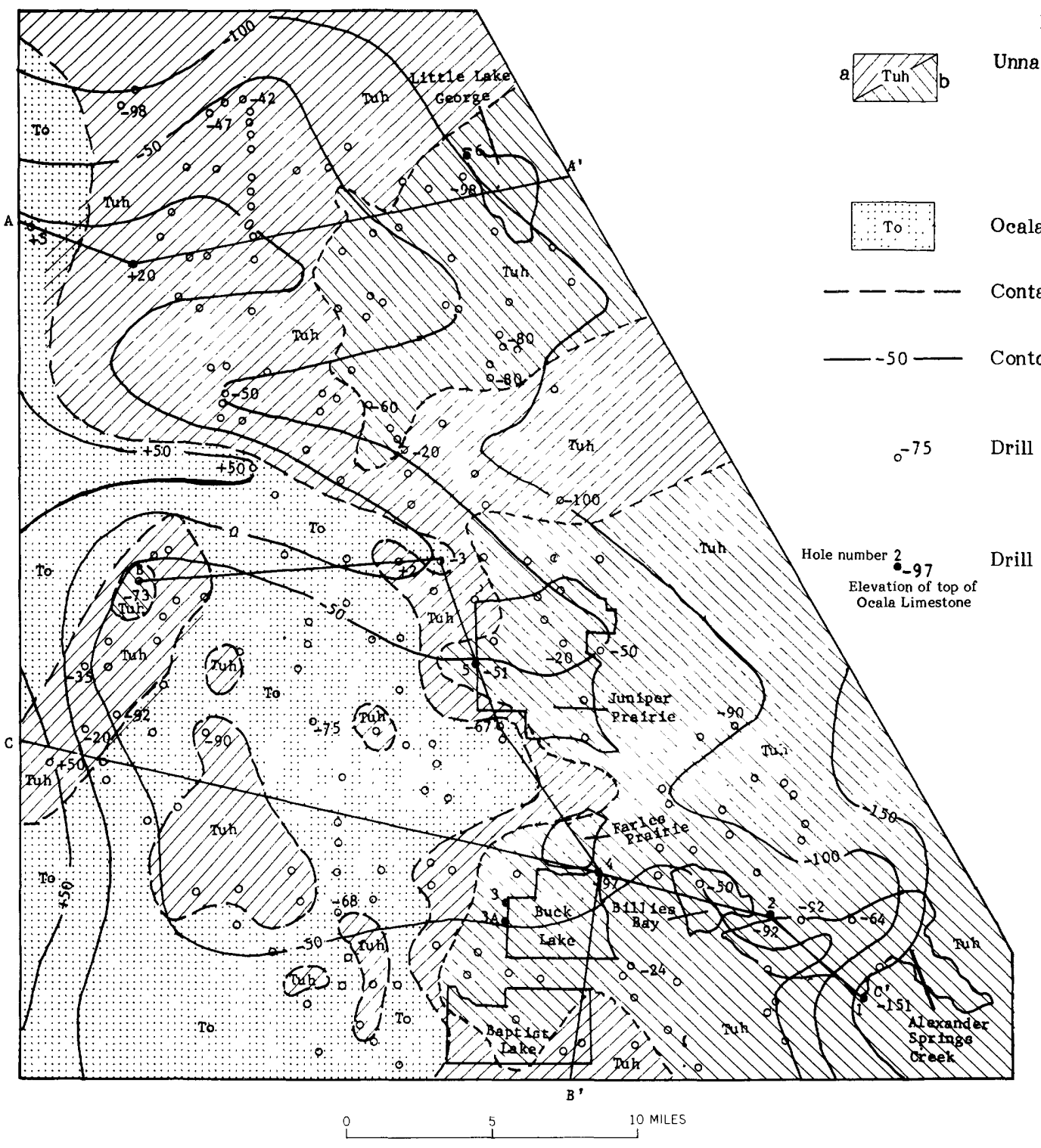

EXPLANATION

nnamed formation (upper Miocene) and Hawthorn Formation (Miocene)-(a) combined thickness of formations is less than $25 \mathrm{ft}$; (b) combined thickness of formations is more than 25 $\mathrm{ft}$

cala Limestone (Eocene)

ontact between Ocala Limestone and Hawthorn Formation

ontours on top of Ocala Limestone, datum is approximately mean sea level, contour interval $50 \mathrm{ft}$

rill hole number is elevation ( $f t$ ) of top of the Ocala Limestone. Holes without numbers indicates that the Ocala Limestone was not reached

Drill hole this study (USGS-USBM, 1980). Elevations determined from core drilling during this investigation, logs described by Espenshade and Spencer (1963) and from stratigraphic interpretation of lithologic logs of company drill holes

Figure 3.-The extent of the phosphate-bearing unnamed upper miocene formation and Hawthorn Formation, the Ocala Limestone, locations of drill holes, and structure-contour map of part of the Ocala National Forest. 

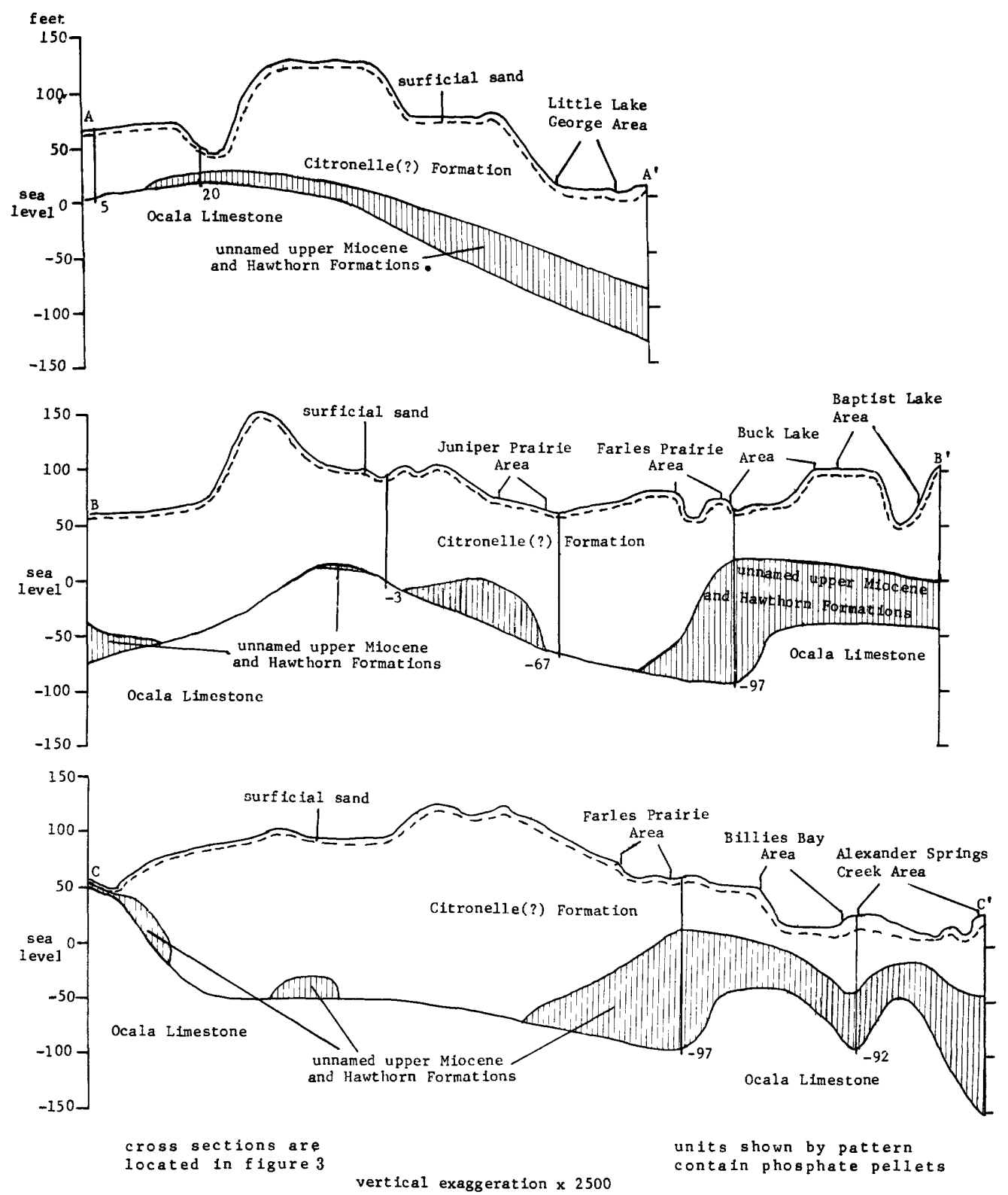

\section{Diagrammatic cross section showing the relation of the unnamed upper Miocene formation and Hawthorn Formation to other strata.}




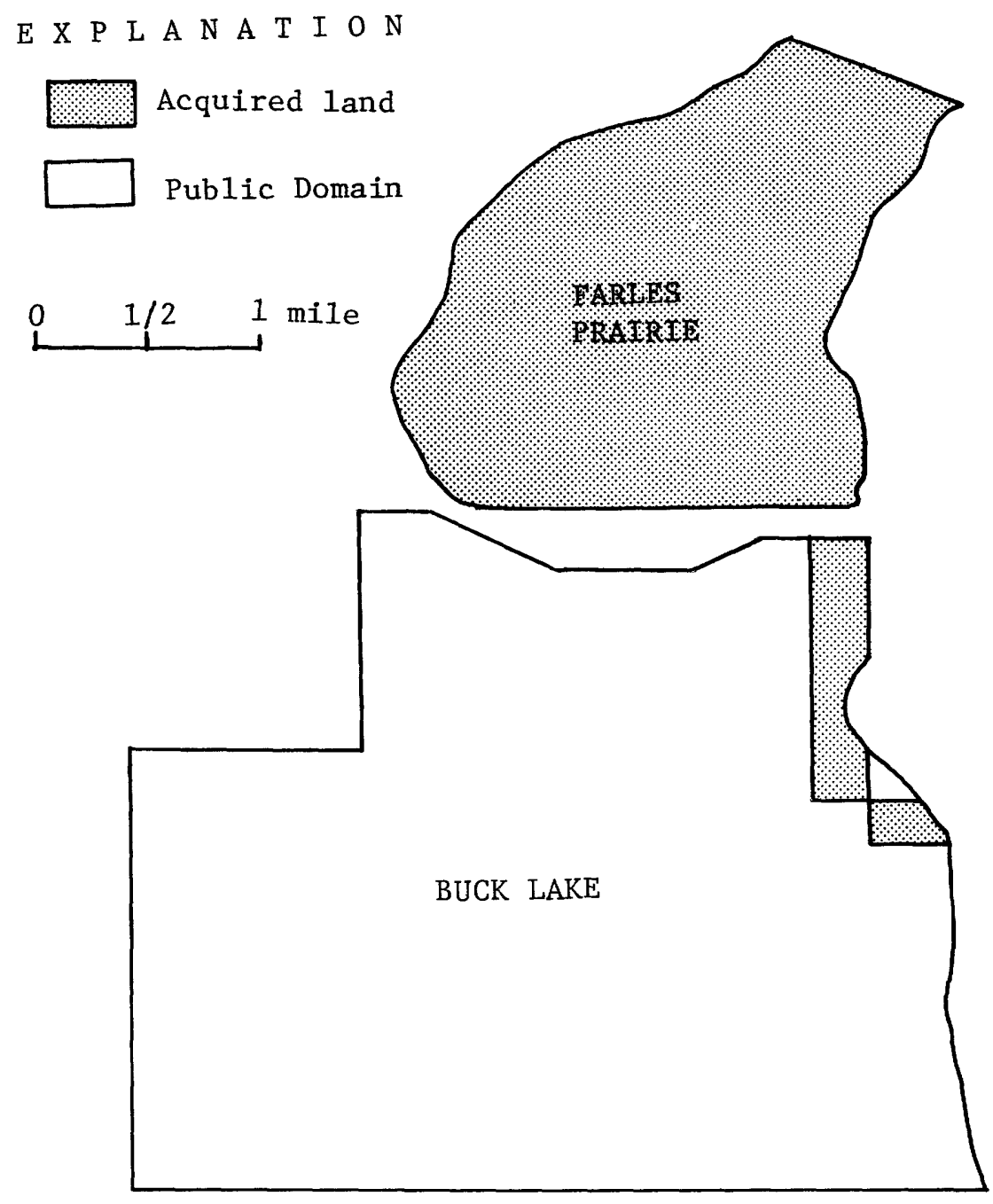

Figure 4.-Land-status map. 
study areas as shown on the geologic map (fig. 3). The Citronelle(?) Formation rests unconformably on an unnamed formation considered to be upper Miocene in age. The unnamed formation overlies fossiliferous sediments of the Hawthorn Formation. The Haw thorn Formation, as well as the unnamed formation, underlie the Farles Prairie and Buck Lake Roadless Areas and areas to the east, but they have been eroded from the westernmost part of the Ocala National Forest, where the Citronelle(?) Formation rests directly on the Ocala Limestone. The Ocala Limestone underlies all of the Ocala National Forest. More than three thousand feet of sedimentary rocks, ranging in age from Cretaceous to Eocene (fig. 2, table 1), underlie the Ocala Limestone, and Cretaceous rocks rest unconformably on an older basement of crystalline and sedimentary Paleozoic rocks.

\section{STRATIGRAPHY}

Studies of cuttings and drill core from the dry holes (Applin, 1951; Puri and Vernon, 1964; Bridge and Berdan, 1952; Milton, 1972) have revealed the presence of crystalline and Paleozoic rocks at depth in the region of Farles Prairie and Buck Lake. Crystalline rocks were penetrated in six dry holes (fig. 2, table 2), the rock type and depth intervals are as follows: a) tuff or welded tuff-hole $6(3,879-3,881 \mathrm{ft})$, hole 8 $(4,60 \mathrm{l}-4,642 \mathrm{ft})$, and hole $17(4,615-4,637 \mathrm{ft}), \mathrm{b})$ basalthole $13(4,344-4,377 \mathrm{ft})$, c) rhyolitic volcanic rock-hole $19(5,424 \mathrm{ft})$, and d) dioritic rock-hole $21(5,952-5,956$ ft). The basalt in hole 13 overlies Lower Ordovician black shale, and hole 17, which passed through tuff, bottomed in Lower Ordovician quartzite. Lower Ordovician quartzite, sandstone, or shale was penetrated by holes $1,3,4,12,14,15$, and 17 .

\section{MESOZOIC ERA}

\section{Cretaceous system}

According to Applin and Applin (1965), Cretaceous strata rest unconformably on Paleozoic rocks in the region of Farles Prairie and Buck Lake areas. The Lower Cretaceous beds penetrated by hole 19 (fig. 2, table 5), located northwest of the area, consist of three major stratigraphic units (Applin and Applin, 1965, plate 6). The lower unit, of Trinity age, is composed of sandstone and shale overlain by dolomite. The middle unit, of Fredericksburg age, is chiefly dolomite, and the uppermost of the three units, of Washita age, is limestone and shaly sandstone. The total thickness of the three units is about $630 \mathrm{ft}$. The Upper Cretaceous beds penetrated by hole 17 (fig. 2) located west of Buck Lake, are divided into four major units having a total thickness of nearly 1,600 ft (Applin and Applin, 1967, plate 7). The Atkinson Formation, the lower unit, consists of basal beds of conglomerate, sandstone, and chalk, that are overlain by chalk and sandy chalk. The second unit, consisting of beds of Austin age, is mainly chalk containing anhydrite and gypsum inclusions. The third unit, which is of Taylor age, consists of basal beds of dolomite, the middle part is chalk, and the upper part is dolomite. The Lawson Limestone, the uppermost of the four units, is composed of limestone and domolite containing anhydrite and gypsum inclusions.

\section{CENOZOIC ERA}

\section{Paleocene series}

The Paleocene beds in the region of the Farles Prairie and Buck Lake Roadless Areas are assigned to the Cedar Keys Limestone (Applin and Applin, 1944, p. 1703-1708; Puri and Vernon, 1964, p. 42). Hole 14, located $35 \mathrm{mi}$ west-northwest of the Farles Prairie Roadless Area (fig. 2), passed through $505 \mathrm{ft}$ of the Cedar Keys Limestone at 1,730-2,235 ft depths. In most of peninsular Florida, the Cedar Keys consists of cream- to tan-colored, hard limestone containing distinctive foraminifers.

\section{Eocene series}

Applin and Applin (1944, fig. 23) recognized five Eocene formations in the region of the Farles Prairie and Buck Lake Roadless Areas. The lowermost is the Oldsmar Limestone that is $445 \mathrm{ft}$ thick $(1,285-1,730 \mathrm{ft}$ depths) where penetrated by dry hole 14 (fig. 2). The Oldsmar is lithologically similar to the overlying Lake City Limestone from which it is separated primarily by a distinctive microfauna. The Lake City Limestone consists of alternating layers of dark brown and chalky limestone. It is $555 \mathrm{ft}$ thick (915-1,285 ft depths) where penetrated by dry hole 14. The beds above the Lake City Limestone form an unnamed nonfossiliferous formation that is $55 \mathrm{ft}$ thick (350-915 ft depths) in dry hole 14. This unnamed formation consists of creamcolored to white, hard, dense, saccharoidal, and porous varieties of limestone. The fourth formation is the Avon Park Limestone. According to Puri and Vernon (1964, p. 52), the Avon Park consists of three general lithologic units. The lower unit is thin-bedded and laminated, finely crystalline dolomite containing layers of lignite and carbonaceous plant remains. The middle unit consists of cream-colored to brown, pasty and fragmental marine dolomite that contains flecks and seams of peat. Abundant bryozoa, foraminifers, and ostracods are concentrated in hard layers interbedded with peat and pasty limestone. The upper lithologic unit is cream-colored to brown, fragmental to pasty marine limestone that contains abundant foraminifers, mollusks, and corals. The Avon Park Limestone is $130 \mathrm{ft}$ thick (230-360 ft depths) in dry hole 14 (fig. 2) (Applin and Applin, 1944, fig. 22). The Ocala Limestone is the uppermost of the five Eocene formations. In many places in peninsular Florida the Ocala can be divided into two members. The lower member is light-cream-colored limestone containing abundant molds and casts of small foraminifers. The upper member is soft, white, chalky, porous coquina made up mainly of large foraminifers. The Ocala is approximately $100 \mathrm{ft}$ thick under the study areas. The Ocala Limestone is overlain unconformably by the Miocene Hawthorn Formation, as no Oligocene beds have been identified in the region.

\section{Miocene series}

Rocks of Miocene age in the Farles Prairie and Buck Lake Roadless Areas include the Hawthorn Formation and an unnamed formation of probable late Miocene age.

Hawthorn Formation-The Hawthorn Formation of early and middle Miocene age is present under the Farles Prairie and Buck Lake Roadless Areas and all of the northern and eastem parts of the Ocala National 
Table 1.--Generalized stratigraphic section in the region of the Ocala National Forest, Fla

\begin{tabular}{|c|c|c|c|c|}
\hline Era & $\begin{array}{l}\text { Series } \\
\text { or system }\end{array}$ & $\begin{array}{l}\text { Formati on or } \\
\text { rock un it }\end{array}$ & $\begin{array}{l}\text { Thickness } \\
\text { in feet }\end{array}$ & Lithology \\
\hline & Holocene & unnamed & $0-100$ & $\begin{array}{l}\text { Sand, clayey, sand, muck, and } \\
\text { humus. }\end{array}$ \\
\hline & $\begin{array}{l}\text { Pleis tocene } \\
\text { and } \\
\text { Pliocene }\end{array}$ & $\begin{array}{l}\text { Citronelle(?) } \\
\text { Formation }\end{array}$ & $20-90$ & $\begin{array}{l}\text { Unconsolidated white, red, and } \\
\text { orange sand and clayey sand. }\end{array}$ \\
\hline & \multirow[b]{2}{*}{ Mi ocene } & $\begin{array}{l}\text { unnamed } \\
\text { format i on }\end{array}$ & $0-70$ & $\begin{array}{l}\text { Sandy clay and clayey sand } \\
\text { containing shell fragments and } \\
\text { phosphate grains. }\end{array}$ \\
\hline & & $\begin{array}{l}\text { Hawthorn } \\
\text { Format i on }\end{array}$ & $0-130$ & $\begin{array}{l}\text { Upper part is sandy clay and } \\
\text { clayey sand with variable amounts } \\
\text { of dolamite grains and phosphate } \\
\text { grains, lower part is chiefly } \\
\text { dolamite containing some phosphate } \\
\text { grains. }\end{array}$ \\
\hline & \multirow{5}{*}{ Eocene } & $\begin{array}{l}\text { Ocala } \\
\text { Limestone }\end{array}$ & 100 & $\begin{array}{l}\text { Cream-colored hard limestone } \\
\text { and chalky l imestone. }\end{array}$ \\
\hline & & $\begin{array}{l}\text { Avon Park } \\
\text { Limes tone }\end{array}$ & 130 & $\begin{array}{l}\text { Dolami te and cream-colored to } \\
\text { brown limestone. }\end{array}$ \\
\hline & & $\begin{array}{l}\text { unnamed } \\
\text { formation }\end{array}$ & 55 & $\begin{array}{l}\text { Cream-colored to whi te hard } \\
\text { limes tone. }\end{array}$ \\
\hline & & $\begin{array}{l}\text { Lake Ci ty } \\
\text { Limes tone }\end{array}$ & 550 & $\begin{array}{l}\text { Layers of brown and chalky } \\
\text { limes tone. }\end{array}$ \\
\hline & & $\begin{array}{l}\text { Oldsmar } \\
\text { Limes tone }\end{array}$ & 450 & Brown and chalky limestone \\
\hline & Pal eocene & $\begin{array}{l}\text { Cedar Keys } \\
\text { Limestone }\end{array}$ & 500 & Cream to $\tan$ hard limestone \\
\hline & \multirow{4}{*}{$\begin{array}{l}\text { Upper } \\
\text { Cretaceous }\end{array}$} & $\begin{array}{l}\text { Lawson } \\
\text { Limes tone }\end{array}$ & \multirow[t]{4}{*}{1600} & Limes tone and dolami te \\
\hline & & $\begin{array}{l}\text { Beds of Taylor } \\
\text { age }\end{array}$ & & Chalk and dolamite \\
\hline & & $\begin{array}{l}\text { Beds of Austin } \\
\text { age }\end{array}$ & & $\begin{array}{l}\text { Chalk containing anhydrite } \\
\text { and gypsum }\end{array}$ \\
\hline & & $\begin{array}{l}\text { Atkinson } \\
\text { Formation }\end{array}$ & & $\begin{array}{l}\text { Conglamerate, sands tone, and } \\
\text { gypsum }\end{array}$ \\
\hline & \multirow{3}{*}{$\begin{array}{l}\text { Lower } \\
\text { Cretaceous }\end{array}$} & $\begin{array}{l}\text { Beds of } \\
\text { Washita age }\end{array}$ & \multirow{3}{*}{630} & Limes tone and shaly sands tone \\
\hline & & $\begin{array}{l}\text { Beds of } \\
\text { Freder i cksburg age }\end{array}$ & & Dolami te \\
\hline & & $\begin{array}{l}\text { Beds of Trinity } \\
\text { age }\end{array}$ & & Limes tone and shaly sands tone \\
\hline & Ordovician & $\begin{array}{l}\text { Crystall ine } \\
\text { and sed imentary } \\
\text { rocks }\end{array}$ & ? & $\begin{array}{l}\text { Basalt, rhyolite, diorite, tuff, } \\
\text { quartzite, sandstone, and shale }\end{array}$ \\
\hline
\end{tabular}


Table 2.--Selected exploratory oil and gas data for the Ocala National Forest and surrounding region (Source: Florida Bureau of Geology, oil and gas reports and records)

\begin{tabular}{|c|c|c|c|c|c|c|c|c|c|c|}
\hline $\begin{array}{l}\text { Florida } \\
\text { Bureau of } \\
\text { Geology } \\
\text { Number } \\
\end{array}$ & $\begin{array}{l}\text { Dry hole } \\
\text { Number } \\
\text { (f1g. 2) } \\
\end{array}$ & $\begin{array}{l}\text { Company or } \\
\text { owrer name }\end{array}$ & $\begin{array}{c}\text { Dry hole or farm } \\
\text { name }\end{array}$ & County & $\mathrm{Sec}$ & $\mathrm{T}$. & R. & $\begin{array}{c}\text { Year of } \\
\text { Completion }\end{array}$ & $\begin{array}{l}\text { Elevation } \\
\text { of Derrick } \\
\text { floor }\end{array}$ & $\begin{array}{l}\text { Tolal } \\
\text { depth of } \\
\text { hole (ft) }\end{array}$ \\
\hline 49 & 1 & $\begin{array}{l}\text { Tidewater } \\
\text { Asaociated } 011 \mathrm{co} .\end{array}$ & R.H. Cato \#1 & Alachua & 23 & $8 \mathrm{~S}$ & $18 \mathrm{E}$ & 1947 & 112 & 3150 \\
\hline 709 & 2 & Chevron $011 \mathrm{Co}$. & $\begin{array}{l}\text { "1 Fred s. } \\
\text { Donaldson et al. } \\
\text { and Contafner Corp. } \\
\text { of America }\end{array}$ & Alachua & 34 & $8 \mathrm{~S}$ & $21 \mathrm{E}$ & 1974 & 150 & $33 / 40$ \\
\hline 52 & 3 & $\begin{array}{l}\text { Tidewater } \\
\text { Assoclated ofl } \mathrm{Co} \text {. }\end{array}$ & II J.A. Phifer & Alachua & 24 & 9S & $21 \mathrm{E}$ & 1947 & 132 & $3288^{1}$ \\
\hline 58 & 4 & $\begin{array}{l}\text { Sun oil Co.-- } \\
\text { Seaboard ofl co. }\end{array}$ & Q.I. Roberts & Putnam & 19 & 9S & $25 \mathrm{E}$ & 1947 & 206 & 3327 \\
\hline 238 & 5 & The Texas Co. & N1 Albert M. Creighton & Alachua & 16 & $11 \mathrm{~s}$ & $19 \mathrm{E}$ & 1955 & 77 & 3527 \\
\hline 96 & 6 & Sun $011 \mathrm{Co}$ & $\# 1$ H.E. Westburg et al & Putnam & 27 & $11 \mathrm{~s}$ & $26 \mathrm{E}$ & 1949 & 32 & $3892^{1}$ \\
\hline 607 & 7 & $\begin{array}{l}\text { Gilbert E. Thayer } \\
\text { and Ssm Davis }\end{array}$ & $\begin{array}{l}\text { Johnson-Ha1phure, } \\
\text { Inc. \#1 }\end{array}$ & Putnam & 27 & $11 \mathrm{~s}$ & $27 \mathrm{E}$ & 1972 & 34 & 5572 \\
\hline 44 & 8 & $\begin{array}{l}\text { Humble } 011 \text { and } \\
\text { Refining Company }\end{array}$ & J.W. Campbe11 et ux & Flsgler & 8 & $11 \mathrm{~s}$ & $28 \mathrm{E}$ & 1947 & 31 & 4633 \\
\hline 199 & 9 & Sphinx Syndicate & Prudential Timber Co. & Levy & 31 & $13 \mathrm{~s}$ & $16 \mathrm{E}$ & 1954 & 26 & 38.57 \\
\hline 110 & 10 & $\begin{array}{l}\text { J. A. Abbott, } \\
\text { Trustee }\end{array}$ & Prudential Timber Co. & Levy & 34 & $13 \mathrm{~s}$ & $16 \mathrm{E}$ & 1950 & 18 & 2013 \\
\hline 69 & 11 & $\begin{array}{l}\text { Carl M. Brunken- } \\
\text { feld Syndicate }\end{array}$ & Levy-Lennon & Levy & 5 & $14 \mathrm{~S}$ & $16 \mathrm{E}$ & 1949 & 17 & 2173 \\
\hline 13 & 12 & Sun $011 \mathrm{Co}$ & J. T. Goethe \#1 & Levy & 31 & $14 \mathrm{~S}$ & $17 \mathrm{E}$ & 1946 & 44 & 39971 \\
\hline 105 & 13 & $\begin{array}{l}\text { Humble } 011 \text { and } \\
\text { Refining Company }\end{array}$ & $\# 1$ C.E. Robinaon et ux & Levy & 19 & $16 \mathrm{~S}$ & $17 \mathrm{E}$ & 1949 & 46 & 4609 \\
\hline w9el & 14 & J.S. Cosden & W.L. Lawson \#1 & Marion & 25 & $13 \mathrm{~s}$ & $20 \mathrm{E}$ & 1928 & 195 & 43341 \\
\hline 101 & 15 & Sun $011 \mathrm{Co}$ & H.T. Parker & Martion & 24 & $14 \mathrm{~S}$ & $22 \mathrm{E}$ & 1949 & 79 & $3845^{1}$ \\
\hline W18 & 16 & Ocala oll Co. & $\begin{array}{l}\text { Clark-Ray Johnson } \\
\text { (York) }\end{array}$ & Marion & 10 & $16 S$ & $20 \mathrm{E}$ & 1928 & 80 & $6180^{l}$ \\
\hline 53 & 17 & Sun $011 \mathrm{Co}$. & "1 Henry N. Caup & Marion & 16 & $16 \mathrm{~S}$ & $23 \mathrm{E}$ & 1947 & 74 & 46371 \\
\hline 785 & 18 & $\begin{array}{l}\text { Amoco Product lon } \\
\text { Coupany }\end{array}$ & 1 U.S.A. $(6-4)$ & Marion & 6 & $15 s$ & $25 \mathrm{E}$ & 1975 & 76 & 4102 \\
\hline 78 & 19 & Grace Drtlling Co. & Retall Lumber Co. & Volusta & 2 & $15 s$ & $30 E$ & 1949 & 44 & $5424^{7}$ \\
\hline 795 & 20 & $\begin{array}{l}\text { Amoco Product lion } \\
\text { Compariy }\end{array}$ & $\# 1$ U.S.A. $44(29-13)$ & lake & $\operatorname{trre}$ & eg. $t$ & ract 44 & 1975 & 56 & 5893 \\
\hline 19 & 21 & Sun $011 \mathrm{Co}$. & "1 Powell Land Co. & Volusia & & $17 \mathrm{~s}$ & $31 \mathrm{E}$ & 1946 & 48 & $5958^{1}$ \\
\hline
\end{tabular}

${ }^{1}$ hole penetrated Paleozoic strata (Puri and Vernon, 1964, plate 1) 
Forest, but has been eroded from the higher parts of the Peninsular Arch to the west, and is present only as irregular erosional remnants in the southwestern part of the forest (fig. 3). The line on the map that represents the western limit of the area where the Hawthorn Formation is unbroken is based on drilling data and matches closely the line on the geologic map by Espenshade and Spencer (1963) that indicates the contact between the Ocala Limestone on the west and younger Hawthorn and Citronelle(?) Formations on the east.

The Hawthorn Formation can be divided into an upper, dominantly clastic unit and a lower, dominantly carbonate unit, based on the drilling done for this project. This division can also be inferred from the lithologic logs of the company drill holes in the Ocala National Forest. The units vary in thickness, but where best developed in the eastern part of the forest, the two units are more or less equal in thickness; toward the west the lower carbonate unit is thicker than the upper clastic unit because of erosion of the upper unit.

The carbonate rock of the lower unit of the Hawthorn Formation is almost entirely dolomite, although some calcite is present as fossil shell material and as yellow-brown elongated "rice-grain" crystals. The dolomite is hard, dense to finely crystalline, and contains abundant rounded grains of phosphate. The phosphate grains range in size from fine sand or silt to granule, are highly polished and well rounded, and are predominantly dark-colored (shades of brown, black, and gray) although some light gray to almost white grains are present. Most of the grains are structureless, some may be internal molds of fossils, and others are phosphatized rock fragments. The rock fragments have the same texture as the dolomite, and probably represent a replacement, by phosphate, of the original groundmass. The carbonate unit in the eastern part of the forest ranges in thickness from 0 to about $90 \mathrm{ft}$, and although no trends in thickness could be seen in this area, there is a general regional thickening to the east and south, away from the crest of the Peninsular Arch.

The clastic rocks of the upper unit of the Hawthorn Formation consist of clay, sand, variable amounts of fine-grained dolomite rhombs, and abundant rounded and highly polished black, brown, gray, and white phosphate pellets. The phosphate pellets tend to be very fine to medium sand size, but some coarse sand to granule size pellets are present. The rocks are gray green to olive green when wet, but are light gray to almost white when dry. Clay minerals include attapulgite (palygorskite) and smectite (montmorillonite), and some sepiolite.

Most of the clastic beds in the Hawthorn Formation in this area are clayey sand; there are some clay beds, however, and all beds are lenticular. An olive green clay bed, $86-90 \mathrm{ft}$ below surface in drill hole 4 , contrins only 5 percent, by weight, material greater than $0.1 \mathrm{~mm}$ in diameter. The $-0.1 \mathrm{~mm}$ material is mainly iron-rich smectite. Other minerals included minor attapulgite and trace amounts of quartz, dolomite, and apatite.

The upper unit ranges in thickness from 0 to about $40 \mathrm{ft}$ and it thickens from west to east. The unit does contain some thin, lenticular dolomite beds, but is generally unconsolidated and contains some recoverable phosphate.

Unnamed Upper Miocene Formation-An unnamed upper Miocene Formation of distinctive lithology that ranges in thickness from 0 to almost $\mathbf{7 0}$ $\mathrm{ft}$ is present in cores from the six holes drilled during the prospecting program in the Ocala National Forest (fig. 3). The unit consists of dark-gray to dark olive gray green (almost black) sandy clay to clayey sand containing abundant shell fragments and black phosphate grains. Where best developed, the basal part of the formation contains abundant "pea" size quartz and black phosphate grains. This may represent a basal conglomerate indicating a break in deposition.

The shell material in the unnamed Upper Miocene formations consists of calcite and aragonite, whereas fragmental shell material in the Hawthorn Formation is entirely calcite. The clay mineral in this post-Hawthorn unit is predominantly smectite, although some attapulgite is present in those samples that are just above the contact with the Hawthorn Formation. Dolomite is present in only a few samples; calcite and aragonite are the dominant carbonate minerals. The shell material was too fragmental to be useful in identification, although fragments of a large pecten appeared to be different from the characteristic Hawthorn species. The unnamed formation is separated from the overlying Citronelle(?) Formation by a distinet difference in lithology. This upper contact may also be unconformable or disconformable.

All the formentioned data indicate that this unnamed formation is not a part of the Hawthorn Formation, but is separated from it by an unconformity. This unit, clearly younger than the Hawthorn Formation and late Miocene in age, is about equivalent to the Bone Valley Formation of the land pebble phosphate district to the south.

\section{Post-Miocene beds}

Beds of problematic age overlie the Miocene rocks. They consist of unconsolidated orange, red, and white mottled, poorly sorted, subrounded, fine to medium, and in some cases, coarse sand and clayey sand-typical of the lithology of the Pliocene Citronelle Formation (Cooke 1945). The contact with the underlying "black" sandy clay of the upper Miocene is a profound break in lithology and may represent an unconformity. The Citronelle(?) Formation is overlain by white loose surficial sand in the higher elevations, and by sand and some swamp muck in the lower elevations, particularly along the shores of Lake George.

The Citronelle(?) Formation penetrated by core holes drilled during the field investigation ranged from 40 to $60 \mathrm{ft}$; elsewhere in the Ocala National Forest, the unit is as much as $100 \mathrm{ft}$ thick, as indicated by lithologic logs of company drill holes.

The Citronelle(?) Formation was derived from erosion of older rocks in the immediate vicinity and contains a mixture of materials. For example, some samples contained dolomite and apatite fragments mixed with the aluminum phosphate mineral crandallite, and in one sample the aluminum hydroxide mineral gibbsite. The fine fraction from samples from these core holes contained mixtures of attapulgite, smectite, and kaolinite.

The Citronelle(?) Formation contains sediments that are characteristic of unweathered Hawthorn Formation, both upper clastic and lower carbonate, the slightly weathered upper Miocene and thoroughly weathered material. Possible sources for these materials are found in Hawthorn outcrops on the high 
parts of the Ocala Uplift, and in the shallow subsurface close to the area of deposition.

White surficial sand in the higher elevations is probably wind-blown sand of Holocene age. Swamp deposits and sand at lower elevations are probably the same age. These materials are present as thin surficial veneers no more than $5 \mathrm{ft}$ thick at most places, but some company drill-hole logs showed as much as $100 \mathrm{ft}$ of "sand and humus", that are probably sink-hole fillings of Holocene age.

\section{STRUCTURE}

The Mesozoic and Cenozoic sedimentary rocks that underlie the Ocala National Forest dip gently to the east and thicken in that direction (fig. 5). The area is on the east flank but close to the crest of the Peninsular Arch, a broad anticline that extends in a southeast direction from Hamilton County on the north to Palm Beach County on the south, a distance of about $300 \mathrm{mi}$ (Applin and Applin 1967). In the Ocala National Forest, Cenozoic rocks are about $2,600 \mathrm{ft}$ thick and Cretaceous rocks are about $1,500 \mathrm{ft}$ thick. To the east, at dry hole 19, Cenozoic rocks are about $3,100 \mathrm{ft}$ thick and Cretaceous rocks are 2,300 ft thick (fig. 5).

The top of the Ocala Limestone is at $50 \mathrm{ft}$ above sea level at the western edge of the Ocala National Forest and is $100 \mathrm{ft}$ below sea level at the eastern edge (fig. 3), confirming the general shallow dip to the east. However, the surface of the top of the Ocala is irregular. There is a ridge or high trending northwest-southeast in about the center of the map, with distinct lows both north and south of the high. These features may be due in part to erosion, but they probably also reflect local structure.

No faults have been recognized in the area, but the northwest-southeast trending high on the Ocala surface (fig. 3) may have been caused by the slumping of blocks on either side into solution cavities. The Hawthorn Formation is thin or absent on the high and thickens markedly in the lows, both to the north and to the south. Probably the crustal movement that formed the Peninsular Arch continued through Miocene time and the high was present during deposition of the Hawthorn Formation. This would account for the westward thinning of the Hawthorn Formation (fig. 3), inasmuch as deposition would have been restricted and erosion more active in the higher areas.

\section{ASSESSMENT OF MINERAL RESOURCE POTENTIAL}

Limestone, clay, sand, and peat are produced in the region in which the Farles Prairie and Buck Lake Roadless Areas are located (fig. 2). Hard-rock phosphate was produced many years ago from small mines located along and near the crest of the Peninsular Arch some $40 \mathrm{mi}$ to the west, and phosphate is being produced from mines in Hamilton County about $100 \mathrm{mi}$ to the north and from Polk and Hillsborough Counties about $90 \mathrm{mi}$ to the south. Inferred subeconomic phosphate deposits underlie much of the study areas, but total tonnage and grade cannot be estimated with existing prospect data. Extensive deposits of limestone underlie the areas, but are deeply buried. No heavy-mineral concentration rich enough for mining is known in the area. Although beds of clay are known to be present, they are probably lenticular and are deeply buried. No peat deposits are known in the area. Clayey sand has been dug in the area for use in construction of Forest Service roads; none is being mined at the present. The area has a low resource potential for oil and gas.

\section{PHOSPHATE}

The phosphate deposits of central peninsular Florida are in the southernmost part of the north Florida-south Georgia district. Phosphate is present in the Hawthorn Formation and in younger rocks from which most of the phosphate has been reworked from the Hawthorn (Catheart, 1968).

In the late $1960^{\prime}$ 's, several phosphate companies drilled about 200 holes in the Ocala National Forest (fig. 3). Most drill hole cores contained so little phosphate that samples were not analyzed, and no commercial deposits were found.

However, the Hawthorn Formation has been removed by erosion on the higher parts of the Peninsular Arch; it is present as erosional remnants in the westernmost part of the Ocala National Forest (fig. 3). The formation is present throughout the eastern part of the forest where drill-hole data show that it ranges from 20 to about $90 \mathrm{ft}$ in thickness. Moderate concentrations of phosphate are present in the upper part of the Hawthorn Formation and in rocks of probable late Miocene age that overlie the Hawthorn Formation.

\section{Characteristics of Minable Phosphate Deposits}

The economic limits for phosphate deposits are listed below. The maxima and minima listed are estimates of industry standards, based on current company practices. None of the criteria are absolute, but are interdependent. For example, a deposit with very high $\mathrm{P}_{2} \mathrm{O}_{5}$ content probably could be mined even if the tonnage numbers were below the minimum listed here.

1.--The phosphorus content is expressed as percent phosphorus pentoxide $\left(\mathrm{P}_{2} \mathrm{O}_{5}\right)$ or percent bone phosphate of lime (BPL). Chemically, BPL is equal to tricalcium phosphate $\left(\mathrm{Ca}_{3}\left(\mathrm{PO}_{4}\right)_{2}\right)$ and is equal to percent $\mathrm{P}_{2} \mathrm{O}_{5} \times 2.185$. The minimum in minable deposits is 60 percent $\mathrm{BPL}$ or about 28 percent $\mathrm{P}_{2} \mathrm{O}_{5}$.

2.--Excess amounts of iron, aluminum, calcium, and magnesium are deleterious in phosphate deposits. Maximum iron and aluminum (expressed as the oxides $\mathrm{Fe}_{2} \mathrm{O}_{3}+\mathrm{Al}_{2} \mathrm{O}_{3}$ ) allowable in commercial deposits is 5 percent, and the maximum magnesium ( $\mathrm{MgO})$ is 1.0 percent. Calcium is present in the minerals apatite, calcite, and dolomite. The ratio of $\mathrm{CaO}$ (in percent) to $\mathrm{P}_{2} \mathrm{O}_{5}$ (in percent) in apatite ranges from about 1.40 to about 1.55; the maximum ratio allowable is about 1.60 .

3.-The minimum minable tonnage, expressed as recoveragle phosphate tons per acre per foot of thickness (tons per acre-foot) is 400 , which is equal to about 20 percent, by weight, of recoverable phosphate particles (pebble + concentrate).

4.-Minimum minable thickness of a phosphate bed is about $3 \mathrm{ft}$, which is the least thickness that can be mined with large draglines.

5.-Thickness of overburden that can be removed in profitable mining is expressed as the ratio of 
this thickness to the thickness of the phosphate bed. The maximum is about 5 to 1 .

6.-The present maximum thickness of overburden plus phosphate that can be mined profitably in Florida is about $200 \mathrm{ft}$; however, this maximum applies only to high-grade deposits where the phosphate bed is more than $25 \mathrm{ft}$ thick. Maximum limits of depth of phosphate strip mining in northern peninsular Florida are presently no more than $150 \mathrm{ft}$.

\section{Company Prospecting Data}

The prospect drilling of the 1960's was more or less uniformly distributed throughout the area of the Ocala National Forest (fig. 3). The drilling density was about 15-20 holes per township, or about one hole for each two square miles. Many of the drill holes did not penetrate deep enough to reach the Hawthorn Formation or the upper Miocene, but were stopped at a pre-determined depth ( 50 to $55 \mathrm{ft}$ ), or were abandoned because of caving of loose surficial sand.

\section{Evaluation of the Phosphorite of the Farles Prairie- Buck Lake Roadless Areas}

Overburden-The overburden includes all of the non-economic materials that overlie the phosphate deposit. Stratigraphically it includes unconsolidated sediments of possibly Pliocene, Pleistocene, and Holocene ages. Company data show that the overburden in the Farles Prairie-Buck Lake Roadless Areas ranges from 50 to about $100 \mathrm{ft}$ in thickness and averages about $70 \mathrm{ft}$. Overburden thickness of the holes drilled in the field program are more or less uniform, as indicated by holes $3,3 \mathrm{~A}$, and 4 (fig. 3 ) that penetratd 48,50 , and $68 \mathrm{ft}$ of overburden, respectively. Both holes drilled to the east of the area (fig. 3, holes 1 and 2) penetrated $75 \mathrm{ft}$ of overburden, so there may be a tendency for the overburden to thicken to the east.

Phosphorite-Phosphorite intersected by company drill holes ranges in thickness from 0 to about $90 \mathrm{ft}$, and averages about $30 \mathrm{ft}$. In the holes drilled during the field program, the phosphate deposit included the clastic upper unit of the Hawthorn Formation and the sandy, shelly, phosphorite of the unnamed upper Miocene Formation. Total thickness of the phosphorite in these drill holes ranges from $3 \mathrm{ft}$ (fig. 3 , hole $3 \mathrm{~A}$ ) to about $53 \mathrm{ft}$ (fig. 3 , hole 1 ).

Data on thicknesses of overburden and phosphorite from company drilling and from holes drilled during the field investigation (fig. 3) show that the total depth (overburden plus phosphorite) is less than the $150 \mathrm{ft}$ maximum, and that the ratio of overburden thickness to ore thickness falls within possible economic limits.

Only $\mathrm{P}_{2} \mathrm{O}_{5}$ analyses are available from the records of company drilling and they are for 39 samples of pebble $(+14$ mesh) and 13 samples of concentrate $(-14+150$ mesh). The pebble fraction contains 0.9 to 29.6 percent $\mathrm{P}_{2} \mathrm{O}_{5}$ and averages about 500 tons per acre foot. The low $\mathrm{P}_{2} \mathrm{O}_{5}$ content and the high tonnage of these samples indicate that they contain a high percentage of quartz or dolomite in addition to apatite. The concentrate samples contain 21.6 to 32.8 percent $\mathrm{P}_{2} \mathrm{O}_{5}$ and average 29.6 percent. The relatively high $\mathrm{P}_{2} \mathrm{O}_{5}$ content of the concentrate fractions may be due to the method of selection of these samples-i.e., only the samples that contained abundant phosphate were analyzed. Analytical data for the pebble and concentrate fractions separated from the drill cores taken during the field investigation are shown in tables 3,4 , and 5 . The $\mathrm{P}_{2} \mathrm{O}_{5}$ contents of the pebble fraction of the Hawthorn and the unnamed upper Miocene formation (tables 3 and 5) range from 9.88 to 18.67 percent, except for one sample from drill hole 4 that contained 31.49 percent $\mathrm{P}_{2} \mathrm{O}_{5}$. The concentrate fractions (tables 4 and 5) contain from 21.81 to 31.23 percent $\mathrm{P}_{2} \mathrm{O}_{5}$, much higher than for the pebble samples.

Total $\mathrm{Fe}_{2} \mathrm{O}_{3}+\mathrm{Al}_{2} \mathrm{O}_{3}$ contents of pebble samples taken during the field investigation (tables 3 and 5) range from 1.43 to 2.51 percent. The content of $\mathrm{MgO}$ in these samples ranges from 0.32 to $\mathbf{5 . 2 2}$ percent, and the ratios of $\mathrm{CaO}$ to $\mathrm{P}_{2} \mathrm{O}_{5}$ are above the ratio for apatite. The contents $\mathrm{Fe}_{2} \mathrm{O}_{3}+\mathrm{Al}_{2} \mathrm{O}_{3}$ in the concentrate fraction range from 1.68 to 3.98 percent; $\mathrm{MgO}$ contents range from 0.39 to 1.60 percent and the ratios of $\mathrm{CaO}$ to $\mathrm{P}_{2} \mathrm{O}_{5}$ are all above the ratio for apatite.

Thus, the phosphorite in the Farles Prairie-Buck Lake Roadless Areas is not economic by today's standards. Although much of the concentrate fraction contains more than 28 percent $\mathrm{P}_{2} \mathrm{O}_{5}$, the pebble fraction averages only about 13 percent. Tonnages of acceptable material are too low, contents of $\mathrm{MgO}$ and $\mathrm{CaO}$ are slightly high, but iron and alumina contents are below the maximum.

Although not minable today, the phosphorite in the area is a subeconomic resource that will increase in value as the reserves presently being mined elsewhere are exhausted. Data from the scattered drilling indicate that the best phosphate is in the eastern parts of the Farles Prairie-Buck Lake Roadless Areas.

Uranium-Uranium is present in all marine phosphorites in amounts that typically range from 10 to $300 \mathrm{ppm}$ (Catheart, 1978). The uranium is syngenetic in origin and substitutes for calcium in the apatite structure.

Analyses of samples from the core drilling of this study (table 6) show that the pebble fraction contains more uranium than the concentrate fraction. Samples of phosphorite from the unnamed upper Miocene formation are slightly higher in uranium than samples from the Hawthorn. Slime (-150 mesh) samples are distinctly lower in uranium than either the pebble or the concentrate samples and contain very nearly the same amount of phosphate as the head (total rock) samples. These generalizations are very similar to data from the minable deposits of south Florida (Polk and Hillsborough counties) and north Florida (Hamilton County) (Cathcart, 1956). Uranium has been recovered as a by-product of the manufacture of phosphoric acid at several plants in the land-pebble district.

Trace elements-The suite of trace elements in phosphorite samples from the Ocala National Forest (table 7) is similar to that of other phosphate deposits. The elements associated with apatite (uranium, strontium, lanthanum, and scandium) have about the same abundance as in phosphate deposits of the Phosphoria Formation in Idaho (Gulbrandsen, 1966), reflecting the fact that $\mathrm{P}_{2} \mathrm{O}_{5}$ contents in the two deposits are comparable. Elements thought to be associated with organic matter (table 7) are less abundant in samples from the Hawthorn Formation, which contains much less organic material than the Phosphoria Formation. The elements in organic 
Table 3.--Analytical and mineralogic data, pebble $(+1 \mathrm{~mm})$ fraction of the upper clastic unit, Hawthom Formation, Ocala National Forest (Chemical analyses by Pembroke Laboratories, Barlow, Fla.)

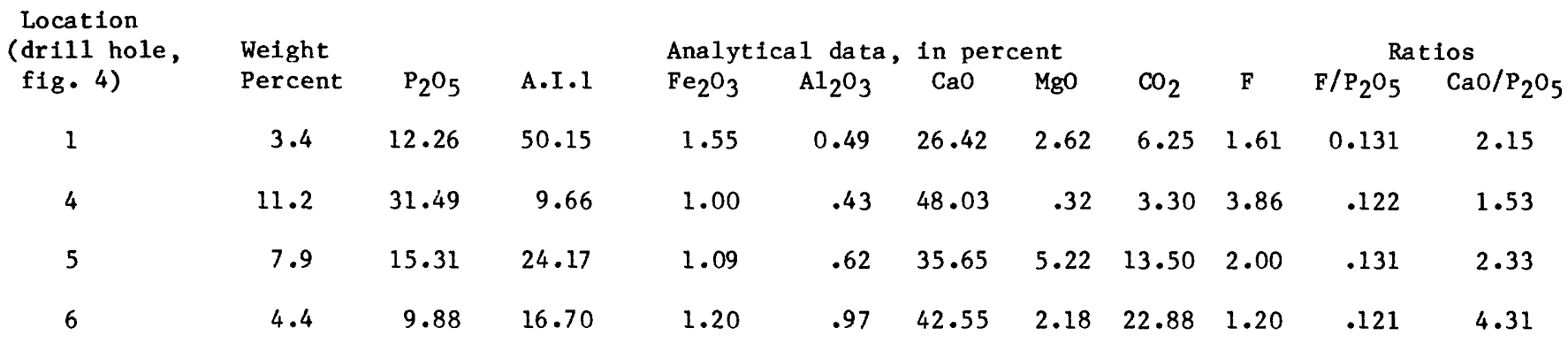

1 Acid Insoluble

MINERALOGY

(Minerals listed in approximate order of abundance)

1 Quartz, apatite, dolomite, feldspar, pyrite

4 Apatite, quartz, feldspar, dolomite

5 Apatite, dolomite-quartz, pyrite, feldspar

6 Calcite, apatite, quartz, dolomite, feldspar, pyrite

Table 4. Analytical and mineralogic data, concentrate $(-1 \mathrm{~mm}-+1 \mathrm{~mm})$ fraction of the upper clastic unit, Hawthorn Formation, Ocala National Forest (Chemical Analyses by Pembroke Laboratories, Inc.

\begin{tabular}{|c|c|c|c|c|c|c|c|c|c|c|c|}
\hline \multirow{2}{*}{$\begin{array}{l}\text { Location } \\
\text { (drill hole, } \\
\text { fig. 4) }\end{array}$} & \multirow{2}{*}{$\begin{array}{l}\text { Weight } \\
\text { Percent }\end{array}$} & \multirow[b]{2}{*}{$\mathrm{P}_{2} \mathrm{O}_{5}$} & \multicolumn{5}{|c|}{ Analytical data, in percent } & \multirow[b]{2}{*}{$\mathrm{CO}_{2}$} & \multirow[b]{2}{*}{ F } & \multicolumn{2}{|c|}{ Ratios } \\
\hline & & & A.I. 1 & $\mathrm{Fe}_{2} \mathrm{O}_{3}$ & $\mathrm{Al}_{2} \mathrm{O}_{3}$ & $\mathrm{CaO}$ & MgO & & & $\mathrm{F} / \mathrm{P}_{2} \mathrm{O}_{5}$ & $\mathrm{CaO} / \mathrm{P}_{2} \mathrm{O}_{5}$ \\
\hline 1 & 14.4 & 29.54 & 3.02 & 2.63 & 0.66 & 49.50 & 0.90 & 5.02 & 3.62 & 0.122 & 1.55 \\
\hline 2 & 23.2 & 31.23 & 9.12 & 1.29 & .39 & 47.70 & .39 & 3.75 & 3.68 & .118 & 1.52 \\
\hline 4 & 3.6 & 27.46 & 6.97 & 2.81 & .98 & $44 \cdot 30$ & 1.52 & 5.85 & 3.55 & .129 & 1.61 \\
\hline 5 & 7.7 & 27.94 & 4.18 & 1.29 & .71 & 47.78 & 1.60 & 7.72 & 3.17 & .114 & 1.71 \\
\hline 6 & 10.30 & 26.60 & 8.22 & 1.80 & .76 & 46.42 & .99 & 6.67 & 2.96 & .111 & 1.75 \\
\hline
\end{tabular}

1 Acid Insoluble

MINERALOGY

(Minerals listed in approximate order of abundance)

1 Apatite, quartz, pyrite, trace dolomite, feldspar

2 Apatite, quartz, trace pyrite

4 Apatite, quartz, trace dolomite, pyrite

5 Apatite, quartz, trace dolomite

6 Apatite, quartz, trace dolomite, pyrite 
Table 5.--Analytical and mineralogic data, samples from the unnamed upper Miocene formation, Ocala National Forest (Chemical analyses by Pembroke Laboratories, Barlow, Fla.)

Location (dri11 hole. fig. 4)

6

6

1
Analytical data, in percent

A.I. 1
Analyt
$\mathrm{Al}_{2} \mathrm{O}_{3}$$$
\text { ( }
$$

Pebble Fraction (+1 mm)

$22.7 \quad 10.13$

54.38

1.64

0.31

25.47

0.60

17.61

1.85

.49

40.84

1.47

7.07

1.53

0.151

2.51

Mineralogy-Minerals listed in approximate order of abundance.

1 Apatite, quartz, calcite, feldspar

6 Apatite, quartz, calcite, feldspar, dolomite (trace).

Concentrate fraction $(-1 \mathrm{~mm}+0.1 \mathrm{~mm})$

$7.8 \quad 21.81$

2.70

2.26

.52

47.65

.80

14.38

2.96

.64

$45.75 \quad .80$

6.65

3.09

.113

2.18

Mineralogy--Minerals listed in approximate order of abundance

1 Apatite, pyrite, heavy minerals (staurolite, sillimanite, tourmaline, rutile, zircon, garnet, ilmenite, kyanite)

6 Apatite, calcite, quartz, pyrite

Acid Insoluble 
Table 6.--Summary of uranium content of samples of phosphate rock, Ocala National Forest (Analyses in ppm uranium; Analysts: L. J. Sherlock and N. J. Nelson, Branch of Exploratory Research, USGS)

Head (Total rock samples)

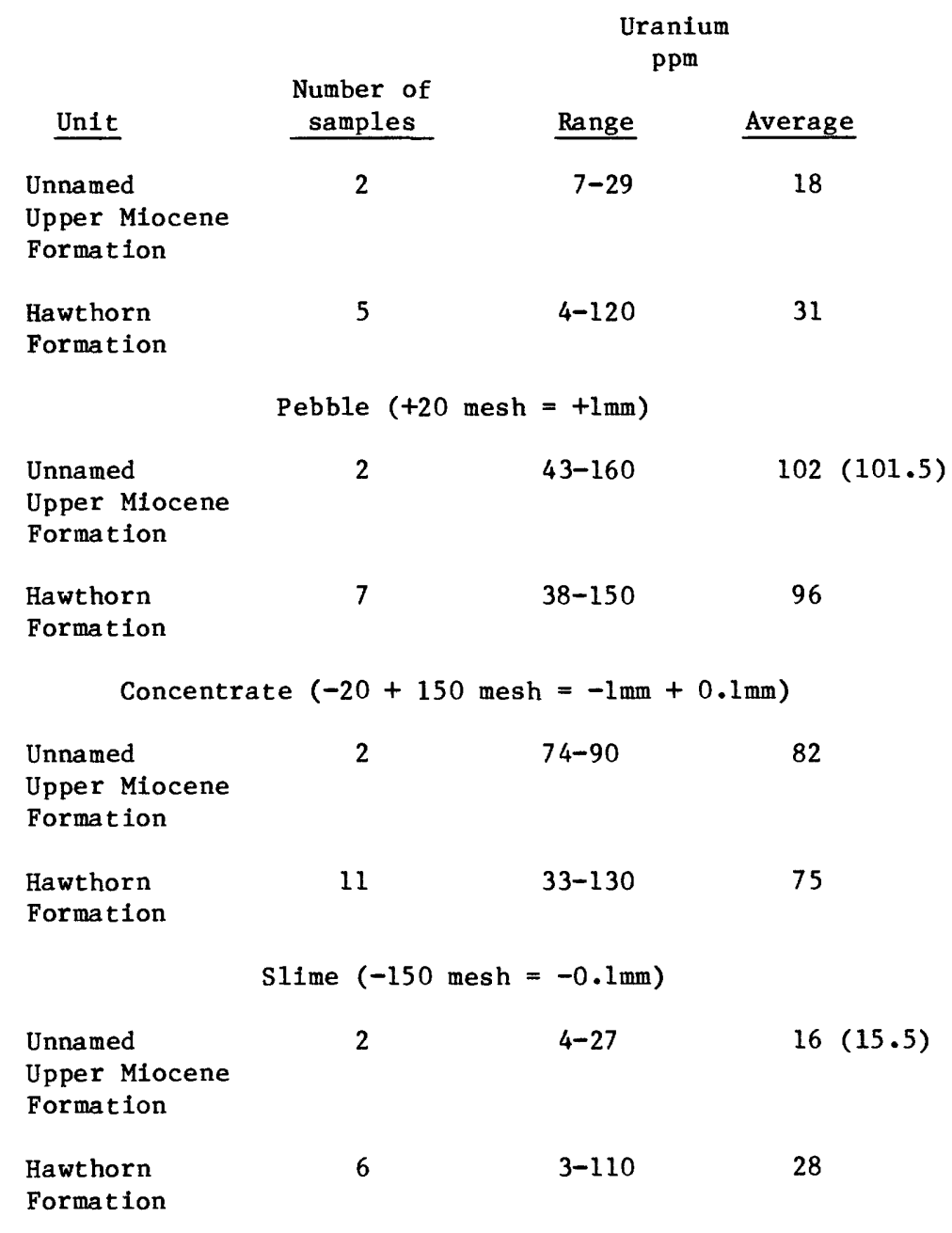


Table 7.--Trace-element contents of phosphorites of the Hawthorn Formation (this paper) and the phosphorites of the Phosphoria Formation as reported by Gulbrandsen, (1966)

$$
\text { ( } \mathrm{N}=\text { not detected; - = no data; Analyst: Betty Adrian, USGS) }
$$

$\begin{array}{cc}\text { Phosphorite } & \text { Phosphoria Formation } \\ \text { Hawthorn Formation } & \text { (Gulbrandsen, 1966) } \\ \text { ppm 1 } & \text { ppm } 1\end{array}$

Elements probably associated with organic material

$\begin{array}{lrr}\mathrm{Ag} & 0.5 & 3 \\ \mathrm{As} & -- & 40 \\ \mathrm{Cr} & 200 & 1000 \\ \mathrm{Cu} & 20 & 100 \\ \mathrm{Cd} & \mathrm{N} & 100 \\ \mathrm{Mo} & 15 & 30 \\ \mathrm{Ni} & 20 & 100 \\ \mathrm{Sb} & \mathrm{N} & 7 \\ \mathrm{Se} & -- & 10 \\ \mathrm{~V} & 70 & 300 \\ \mathrm{Zn} & \mathrm{N} & 300\end{array}$

Elements associated with the apatite

$\mathrm{U}$

$\mathrm{Sr}$

La

Y

Sc

$\mathrm{Ba}$

Mn

$\mathrm{Zr}$
852

1000

200

300

10
3

402

1000

100

100

30

100

7

10

300

902

1000

300

300

10

other associations

$200+$

100

30

300

1 The most frequent value reported in the spectrographic analysis

2 Arithmetic average of chemical analyses 
matter probably occur in organic complexes and those in apatite are thought to be in substitution for calcium. The barium and manganese are likely to occur in discrete minerals, for example, manganese may be in pyrolusite, but this mineral has not been identified in these rocks. The higher barium and manganese contents in the Hawthorn Formation is probably related to an oxidizing environment that existed when Miocene sediments were deposited, in contrast to the reducing environment during deposition of the Phosphoria. Virtually all of the zirconium is in zircon, as this resistant mineral withstood transportation and reworking of the sediments before deposition.

\section{CLAY}

Clay is mined from localities both to the north and the west of the Ocala National Forest. Kaolinite is mined in the area near Edgar in T. 10 S., R. $23 \mathrm{E}$., about $40 \mathrm{mi}$ to the north. The kaolinite is from sandy clay of the Citronelle(?) Formation. Clay for fuller's earth is mined from the Hawthorn near Emathla in T. $13 \mathrm{~S} .$, R. $20 \mathrm{E}$., about $38 \mathrm{mi}$ to the west.

Although kaolinite is present in samples from the Citronelle(?) Formation in the holes drilled, the amount of slime ( -200 mesh) in the fraction is lowranging from 4 percent to about 30 percent, and averaging about 15 percent. The slime fraction of the Citronelle(?) Formation also contains abundant quartz and smectite as well as some dolomite and attapulgite. The material, therefore, is such a mixture of minerals that it is very doubtful that there could be any deposits of kaolinite that are even remotely economic.

Smectite is a common clay mineral in the Hawthorn Formation, but examinaton of the core during the drilling showed that almost all samples were very sandy. Only one sample of clay was taken for tests by the U.S. Bureau of Mines. According to Crandall (1981) the sample showed excellent ceramic properties and bloating characteristics. The sample, taken from the interval 86-90 ft below surface at drill hole 4 (fig. 3), was chiefly a high-iron smectite, but $x$-rays show that the sample also contained some attapulgite, quartz, dolomite, and a trace amount of apatite.

The clays in the Farles Prairie-Buck Lake Roadless Areas have no commercial value. They are too impure or too deeply buried.

\section{HEAVY MINERALS}

Heavy minerals have been mined for many years from deposits about 60 airline miles to the north of the Farles Prairie-Buck Lake Roadless Areas. Ilmenite, the ore of titanium oxide, is the principal mineral produced, but staurolite, monazite, zircon, garnet, and kyanite are also recovered (Garner, 1972, 1981). The heavy-mineral deposits are thought to have been concentrated by winnowing action of ocean waves and currents (Pirkle and Yoho, 1970; Garner, 1972, 1981), and are reported to contain about 3 percent of heavy minerals (Pirkle, Pirkle, and Yoho, 1977).

No commercial heavy-mineral deposits are known to be present in the area and none are likely to be found. Surficial sand and the sands of the Citronelle(?) Formation are low in heavy mineralsnine samples of cuttings from the drill holes contained from 0.2 to 0.8 percent and averaged only about 0.4 percent of heavy minerals, which is only about onetenth of the concentration of the commercial deposits. Mineral species found include ilmenite, garnet, zircon, staurolite, rutile, sillimanite, tourmaline, and kyanite, but no monazite has been identified.

\section{LIMESTONE}

The Ocala Limestone is quarried at several localities about $30 \mathrm{mi}$ west of the Farles Prairie Roadless Area, both north and south of the town of Ocala (fig. 2). The limestone underlies all of the Ocala National Forest, and is very pure (Schmidt and others, 1979); according to Mossom (1925) it contains from 96 to 98 percent $\mathrm{CaCO}_{3}$. The amount of limestone present must be enormous, but the top of the Ocala Limestone in the study area is about $100 \mathrm{ft}$ below surface. Abundant resources of limestone, at or close to the surface, are available in the area around the town of Ocala.

Sandy, phosphatic dolomite of the lower unit of the Hawthorn Formation is present under all of the area, but is impure and deeply buried.

\section{PEAT}

Peat, a naturally occurring accumulation of plant remains, is defined as organic material having an ash content not exceeding 25 percent by weight (American Society for Testing Materials, 1969). Commercial peat beds should be $4 \mathrm{ft}$ or more in thickness. Although organic muck and humus deposits are known in low, swampy areas in the Ocala National Forest, the Farles Prairie-Buck Lake Roadless Areas consist mainly of low sand hills, and the surficial sands in the area are very low in organic content (Aydelott and others, 1975). There is no liklihood that any peat deposits are present in the two areas.

\section{SAND}

Slightly clayey sand of the Citronelle(?) Formation mined from a pit in the Buck Lake Roadless Area was used for road metal on Forest Service roads in the area. At the present time, the Forest Service obtains clayey sand from pits outside of the area. The nearest commercial sand operation is near Lynne, about $10 \mathrm{mi}$ to the northwest. Very large resources of sand, close to market areas, are available throughout the region adjacent to the Ocala National Forest.

\section{OIL AND GAS}

Oil and natural gas are produced from Lower Cretaceous Sunniland Limestone in southern Florida and from the Jurassic Smackover Formation in western panhandle Florida. Jurassic beds are not present in the area of the Ocala National Forest, and beds of Early Cretaceous age, present both to the east and west, are missing in the area of the Ocala National Forest, where beds of Late Cretaceous age rest on Paleozoic rocks (Applin and Applin, 1944; U.S. Geological Survey, 1974).

Several exploratory holes for oil and gas have been drilled in and around the Ocala National Forest (fig. 2 and table 5). All holes were dry and abandoned. Two holes were drilled by Amoco Production Co. in the Ocala National Forest (Nos. 18 and 20, table 5). According to Crandall (1981), Amoco 
personnel stated that the primary production target was the Upper Cretaceous Atkinson Formation (fig. 5). The Atkinson Formation is correlated with the Tuscaloosa Formation, from which oil is produced in Alabama and Mississippi (Applin and Applin, 1965)

There is little reason for optimism regarding possible oil and gas resources in the Farles PrairieBuck Lake Roadless Areas because of the number of dry holes in the surrounding areas and because rocks that contain oil and gas elsewhere in Florida are not present here.

\section{REFERENCES CITED}

American Society for Testing and Materials, 1969, D2607-69, Standard classification of peats, mosses, humus, and related products: Philadelphia, Pennsylvania, 1 p.

Applin, P. L., 1951, Preliminary report on buried preMesozoic rocks in Florida: U.S.' Geological Survey Circular 91, 28 p.

Applin, P. L., and Applin, E. R., 1944, Regional subsurface stratigraphy and structure of Florida and southern Georgia: American Association of Petroleum Geologists Bulletin, v. 28, no. 12. 1965, The Comanche Series and associated rocks in the subsurface in central and south Florida: U.S. Geological Survey Professional Paper 447, 86 p.

1967, The Gulf Series in the subsurface in northern Florida and southern Georgia: U.S. Geological Survey Professional Paper 524-G, 34 p.

Aydelott, D. G., Bullock, H. C., Furman, A. L., White, H. O., and Spieth, J. W., 1975, Soil survey of Ocala National Forest area, Florida, parts of Marion, Lake, and Putnam Counties: U.S. Forest Service and U.S. Soil Conservation Service in cooperation with the University of Florida Institute of Food and Agricultural Sciences, Agricultural Experiment Stations Soil Science Department, $64 \mathrm{p}$.

Bridge, Josiah, and Berdan, J. M., 1952, Preliminary correlations of the Paleozoic rocks from test wells in Florida and adjacent parts of Georgia and Alabama: Florida Bureau of Geology Guidebook, Association of American State Geologists 44th Annual Meeting Field Trip, 1952 , p. 29-38.

Calver, J. L., 1949, Florida kaolin and clays: Florida Geological Survey Information Circular 2, $59 \mathrm{p}$.

Catheart, J. B., 1956, Distribution and occurrence of uranium in the calcium phosphate zone of the land-pebble phosphate district of Florida, in Page, L. R., Stocking, H. E., and Smith, H. B., compilers, Contributions to the geology of uranium and thorium by the United States Geological Survey and Atomic Energy Commission for the United Nations International Conference on Peaceful Uses of Atomic Energy, Geneva, Switzerland, 1955: U.S. Geological Survey Professional Paper 300, p. 489-494. 1968, Phosphate in the Atlantic and Gulf Coastal Plains, in Forum on Geology of Industrial Minerals, 4th, Austin, Texas, Proceedings: Texas University Bureau of Econome Geology, p. 23-34. 1978, Uranium in phosphate rock: U.S. Geological Survey Professional Paper 988-A, 6 p.
Cooke, C.W., 1945, Geology of Florida: Florida Geological Survey Bulletin 29, 339 p.

Crandall, T. M., 1981, Mineral resources of the Farles Prairie and Buck Lake RARE II Further Planning Areas, Marion County, Florida: U.S. Bureau of Mines Mineral Land Assessment Report MLA 46-82.

Davis, J. H., Jr., 1946, The peat deposits of Florida, their occurrence, development and uses: Florida Geologeal Survey Bulletin 30, 247 p.

Espenshade, G. H., and Spencer, C. W., 1963, Geology of phosphate deposits of northern Peninsular Florida: U.S. Geological Survey Bulletin 1118, $115 \mathrm{p}$.

Garner, T. E., Jr., 1972, Economic geology of Florida heavy mineral deposits, in Puri, H. S., ed., Proceedings of Seventh Forum on Geology of Industrial Minerals: Florida Bureau of Geology Special Publication 17, p. 17-19.

1981, Heavy mineral industry of North America, in Coope, B. M., ed., Proceedings of the 4th Industrial Minerals International Congress, Atlanta, Georgia, May 28-30, 1980, p. 29-42.

Gulbrandsen, R. A., 1966, Chemical composition of phosphorites of the Phosphoria Formation: Geochim et Cosmochim. Acta, v. 30, p. 769778.

Mansfield, G. R., 1942, Phosphate resources of Florida: U.S. Geological Survey Bulletin 934, 82 p.

Milton, Charles, 1972, Igneous and metamorphic basement rocks of Florida: Florida Bureau of Geology Bulletin No. 55, 125 p.

Mossom, Stuart, 1925, A preliminary report on the limestones and marls of Florida: Florida Geological Survey, 16th Annual Report, p. 27203.

Pirkle, E. C., and Yoho, W. H., 1970, The heavy mineral ore body of Trail Ridge, Florida: Economic Geology, v. 65 , no. 1 .

Pirkle, E. C., Pirkle, W. A., and Yoho, W. H., 1977, The Highland heavy-mineral sand deposit on Trail Ridge in northern peninsular Florida: Florida Bureau of Geology Report of Investigation No. 84,50 p.

Puri, H. S., and Vernon, R. O., 1964, Summary of the geology of Florida and a guidebook to the classic exposures: Florida Bureau of Geology Special Publication No. 5 (revised), 312 p.

Rainwater, E. H., 1971, Possible future petroleum potential of peninsular Florida and adjacent continental shelves, in Cram, I. H., ed., Future petroleum provinces of the United States-their geology and potential: American Association of Petroleum Geologists Memoir 15, v. 2, p. 13ll1341.

Schmidt, Walter, Hoenstine, R. W., Knapp, M. S., Lane, Ed, Ogden, C. M., Jr., and Scott, T. M., 1979, The limestone, dolomite, and coquina resources of Florida: Florida Bureau of Geology Report of Investigations No. $88,51 \mathrm{p}$.

Sever, C. W., Catheart, J. B., and Patterson, S. H., 1967, Phosphate deposits of south central Georgia and north central Peninsular Florida: Georgia Department of Mines, Mining, and Geology, Project Report No. 7, South Georgia Minerals Program, 62 p.

U.S. Geological Survey, 1974, Final environmental statement: proposed oil and gas operations in the Ocala National Forest, Florida, p. 2-19. 